\title{
OS MEDIOS DE COMUNICACIÓN GALEGOS NA SOCIEDADE DO COÑECEMENTO
}

Luís Álvarez Pousa, José Villanueva Rey, Tareixa Barberena Fernández, Óscar Reboiras Loureiro, Antonio Isasi Varela, Ángela Pereira Juvino, Jorge González Fernández, Óscar Curros Moure, Jacobo Rey Sastre, Ana Belén Puñal Rama e Montse Pernas Bellas

Unha das liñas de investigación que máis urxe desenvolver no campo da comunicación e do xornalismo é aquela que máis e mellor responda ás demandas dunha sociedade en transformación, que ten nos medios de comunicación un instrumento imprescindible, mesmo decisivo, para acceder á cantidade de coñecementos que precisa cando tenta interpretar e valorar a complexidade en que se manifesta, no medio de grandes contradicións, o mundo contemporáneo. Nesa perspectiva investigadora, calquera centro de formación de comunicadores pode xustificar a súa razón de ser, quérese dicir, a súa función social, pois é desafiando ese reto como poderá converterse nun referente para a sociedade que o sostén.

O grupo de investigación que traballa desde dentro da Facultade de Ciencias da Comunicación, en Santiago de Compostela, na descuberta do papel que están a cumprir os medios de comunicación galegos na sociedade do coñecemento: a presenza dos expertos e líderes de opinión no discurso xornalístico da prensa, radio, TV e internet, tenta afrontar precisamente ese reto, sumando o seu esforzo investigador ao doutros grupos que o fan tamén por camiños complementarios, conscientes uns e outros da importancia e da necesidade de converter ese centro de formación nun referente para a Galicia do século xxi. Que é a Galicia do presente con futuro.

Á parte dese compromiso xeral co proxecto colectivo que representa a Facultade, o grupo constituíuse cuns obxectivos concretos, que se plasman necesariamente na liña de investigación elixida. Buscouse un campo de traballo innovador e á vez complementario co que está na cerna das investigacións que outros grupos están levando a cabo no mesmo centro e dentro do mesmo 
departamento de Ciencias da Comunicación e que case exclusivamente están referidas ao estudo das estruturas organizativas do sistema comunicativo. O que ten de nova estoutra liña de investigación é que vai moito máis alá de estudar e de analizar as marxes en que a comunicación xornalística marcou a si mesma os límites do permitido -a actualidade convertida en verdade informativa nunca podería desbordar a fisicidade dos feitos-, un obxectivo que no tempo da imaxe en tempo real queda pouco menos que inservible, pero que pode impoñerse como a maior das falacias, aquela segundo a cal Ver equivale sen máis a Coñecer.

Incidirá polo mesmo na necesidade de articular outro modelo de comunicación xornalística que avogue pola complexidade do coñecemento -ou mellor, da interrelación de coñecementospara un máis e mellor achegamento á realidade (á verdade, que sempre está máis alá dos acontecementos). Nesoutro modelo, que hipoteticamente é o da comunicación especializada, os medios e a sociedade do coñecemento confrontarán e axus-tarán mellor os seus respectivos recursos interpretativos e argumentativos. A partir de aí, faise imprescindible avanzar nunha teoría xeral do Xornalismo Especializado, co fin de asentar tanto os seus fundamentos científicos, como o estudo dos ámbitos ou áreas de coñecemento aos que aqueles se poden aplicar. Na perspectiva de que é na cualificación da mediación entre os medios e a sociedade onde terá a súa máis eficaz plasmación.

\section{A INVESTIGACIÓN E AS SÚAS FRONTES}

A revolución tecnolóxica fixo posible a coexistencia de verdades contraditorias: aquelas que se substancian nos efectos homoxeneizadores da globalización, por unha banda, e aqueloutras que son produto seu e actúan subversivamente, facéndolle fronte. Ao espazo de fluxos (o da globalización, o da mundialización), que tentará seguir asentando o vello modelo de sociedade de masas, opónselle o espazo de lugares (o das múltiples e emerxentes identidades, o das culturas, o da diversidade) que referenda outro modelo de sociedade en formación, o da sociedade de colectivos, propio do postindustrialismo. É polo que dicimos que 
entran en crise os conceptos e as realidades por eles representadas de sociedade de masas e de comunicación de masas, que centrarán boa parte dos traballos científicos realizados principalmente polos estudosos norteamericanos.

Parece claro que esa marxe de poder, ou de subversión, está fundamentalmente relacionada co coñecemento e, xa en clave mediática, coa capacidade de acceso a unha información proxectiva, que é preciso entender como aquela que fai posible a comunicación entre os saberes e a sociedade, ou mellor, entre os diferentes ámbitos do saber científico e a sociedade que evoluciona na súa diversidade. É polo que se deduce que os medios actuais non son xa medios de comunicación de masas, senón de produción masiva de información para audiencias segmentadas, sectorizadas, especializadas.

Xa que logo, e desde unha perspectiva teórica, a evolución científico/técnica esixe asumir e afrontar unha progresiva especialización de áreas de coñecemento nas ciencias sociais e non só para os efectos de afondar na súa investigación, senón tamén para facilitar o encontro da ciencia coa sociedade. Iso é o que, por formaren parte das ciencias sociais, se lles esixe igualmente ás ciencias da comunicación, sempre nunha dimensión proxectiva, quérese dicir, axustando o seu obxectivo científico á complexidade coa que se manifesta unha sociedade en transición -entre o modelo de masas e o modelo de colectivos que emerxen cunha forte base identitaria-.

Desde unha perspectiva sistémica, ese axuste ten en catro grandes áreas de coñecemento -sociedade, política, cultura, economía- o seu campo científico/práctico. Nesta dirección, a esixencia cara ás ciencias da comunicación ten que ver cun outro modelo estrutural para a comunicación xornalística, que sería o que mellor responde ás claves da especialización. Atribuiríaselle entón ao xornalismo especializado unha función de sistematización estrutural e de síntese dos contidos informativos que teñen que ver con esas catro grandes áreas de coñecemento.

Medios e xornalistas terán nisto o seu principal reto para a era da información e do coñecemento: partindo de estruturas orga- 
nizativas e de produción axeitadas, ser capaces de integrar nos seus discursos xornalísticos a complexidade coa que se manifestan os acontecementos no tempo da globalización, o que significa rexeitar un pensamento simplificador e apostar por un pensamento complexo. Para maior concreción: que o medio e o xornalista actúen como integradores daqueles coñecementos que, tendo a súa orixe na multiplicidade de xogos (político, social, cultural, económico, medioambiental...), acaben dándolles sentido ás verdades contraditorias que coexisten na sociedade.

\section{OS MEDIOS COMO RECEPTORES E EMISORES DE COÑECEMENTOS}

O grupo pretendeu investigar e analizar os niveis de receptividade que amosan os medios de comunicación galegos respecto da cantidade de coñecementos que, tendo a súa orixe na pluralidade de expertos e creadores de opinión, son susceptibles de entrar a formar parte dos procesos de produción de actualidade, aqueles en que os medios poñen a proba a súa capacidade para faceren frutificar un xornalismo de calidade.

Ligado cos achados aos que se chegue nesa dirección, téntase comprobar mediante unha metodoloxía científica, xa experimentada nos estudos da comunicación para outros ámbitos desta, ata onde a prensa escrita, a radio, a TV e os novos medios que se instalaron en internet apostan ou non en Galicia polo modelo xornalístico que máis e mellor se adapta ás necesidades dunha sociedade multiinformada e cada vez máis sectorizada, na que se produce unha evolución nas maneiras de organizarse e interrelacionarse os colectivos que a integran. Esa dinámica de fragmentación e sectorización explícase atendendo a diversos fenómenos que se estarían producindo tanto en sociedades desenvolvidas como en sociedades subdesenvolvidas, levando estas últimas a peor parte, pois que descargan nelas todo o que as sociedades desenvolvidas rexeitan ou se negan a aceptar.

En primeiro lugar, fenómenos ligados á necesidade que teñen os movementos globalizadores de facer rendible localmente todo o que dá de si a universalización dos fluxos económicos, o 
que produce de facto a creación de comunidades e colectivos de intereses. En segundo lugar, e coa celeridade que impón a necesidade de responder ou mesmo de resistir a todo o que de negativo puideran comportar os obxectivos máis perversos da globalización económica, refórzanse e multiplícanse os movementos identitarios, que favorecen a creación de redes de identidade de resistencia ao global. En terceiro lugar, eses colectivos que medran e se multiplican dotándose de coirazas resistentes de marcado carácter identitario, benefícianse dunha cada vez máis abundante e menos exclusiva información a través de canles que poñen á súa disposición os adiantos tecnolóxicos, así como de todo o que comporta para a socialización e culturización das xentes tanto os procesos de urbanización como de acceso a unha manchea de coñecementos aos que dá vida a actual eclosión da ciencia.

Os medios de comunicación, independentemente do tamaño ou da capacidade de incidencia que teña cada un deles, non poden ignorar estas transformacións. Vailles a vida niso. No fondo, é volver ao que sempre constituíu a cerna da súa función social: encontrarse coa sociedade á que se dirixen alí onde os seus compoñentes teñen que loitar por manterse a salvo de canto os prefire consumidores antes que cidadáns. Nese territorio de confrontación é no que os medios poñen a proba a súa capacidade como produtores de identidade, amais de mediadores para o reequilibrio, que empeza por asumir a súa obriga de descubrir a realidade (política, social, científica, económica, cultural...) interrelacionando coñecementos e saberes.

\section{EXPERTOS E LÍDERES DE OPINIÓN NOS MEDIOS GALEGOS}

En que medida cumpren esas funcións normativas os medios de comunicación galegos? Na resposta a esta pregunta quedará de manifesto ata que punto os medios que integran o sistema galego (prensa escrita, audiovisuais e novos medios) desenvolven a importante e decisiva tarefa de intercomunicar saberes, ou o que é o mesmo, de facelos comunicables a públicos amplos para así acrecentar os niveis de coñecemento, contribuíndo desa maneira a asentar unha democracia verdadeiramente participativa. 
O sistema galego de medios, no seu conxunto e en razón das características que singularizan a uns e a outros soportes, é un obxectivo previo de análise, dado que é preciso contextualizar en que modelos de organización produtiva e de produción propiamente dita acollen os medios o fluxo de coñecementos que teñen a súa orixe na sociedade de emisión e recepción. Deseguido e utilizando unha metodoloxía científica de probada consistencia no ámbito das ciencias sociais, e máis especificamente no campo das ciencias da comunicación e da periodística, concretaremos o volume e a calidade de coñecementos achegados polos expertos e polos líderes de opinión, introducindo as variables necesarias con ese obxectivo. O grao de receptividade de coñecementos que teñan os medios será extraído polo equipo de investigación da análise transversal que relacione os modelos de produción - a capacidade obxectiva dos medios para recibir e producir coñecementos- e a produción en si mesma -a súa cualificación, pluralismo e diversidade-.

Ao tempo, a investigación debe chegar a certos resultados prácticos. Máis en concreto: definir cara ao futuro inmediato baixo que condicións -modelos ou estruturas organizativas e de produción informativa- os medios de comunicación galegos poden seguir respondendo ás demandas dunha sociedade permanentemente sometida a cambios e transformacións que responden tanto a causas esóxenas -os efectos da globalización económica e da cultura tecnocientífica- como a causas endóxenas -nova incardinación xeopolítica, reestruturación do hábitat de poboación, entre outras-.

\section{AVANZANDO NO ESTUDO SOBRE EMISORES-RECEPTORES}

As liñas de investigación no noso ámbito máis próximo -o español e, en xeral, o europeo- centraranse inicialmente nas estruturas organizativas do sistema comunicativo, no márketing comunicacional e de audiencias, nas políticas de comunicación e nos estudos teóricos sobre as Ciencias da Información, tanto desde a perspectiva sociolóxica como semiótica, filosófica e epistemolóxica. Desde a década dos anos 90 do pasado século, a investigación sobre as ciencias da información centrou o seu interese nos novos 
sistemas de información e comunicación. Inicialmente como unha cuestión técnica. É o que deu paso a unha reacción daqueles estudosos que subliñan a necesidade de entender a comunicación como un proceso: un fluxo de mensaxes compartidas que fai xurdir información de seu, que pola súa vez inflúe nos coñecementos e nos valores das persoas.

A teoría xeral da información, que se mantivera nun plano de carácter impersoal, perdeu nesa nova conxuntura científica o seu poder explicativo. Sobre todo, ao se constatar como a explosión tecnolóxica acabou producindo fenómenos que deron finalmente na crise da comunicación de masas, simultánea daqueloutra en que entraron os diferentes movementos de masas que alentaron na sociedade industrial. $\mathrm{O}$ antigo sistema de comunicación de masas está deixándolle paso á sociedade da comunicación interactiva.

É o que motivou que algúns estudosos destes fenómenos da comunicación os denominasen metamorfose mediática, quérese dicir, a transformación á que seguen véndose forzados os diferentes medios de comunicación, para desenvolver as súas funcións na oferta de servizos especiais dirixidos a públicos tamén especiais - cada vez máis fragmentados, sectorizados e especializados-. Do que se deduce a necesidade dun cambio substancial do xornalismo $e$, conseguintemente, unha viraxe de gran angular na investigación que se impón nas ciencias da información á hora de abordar no tempo da sobreinformación as relacións emisor-receptor.

Chegou o momento en que, para avanzar en consonancia con estas transformacións sociais e propiamente mediáticas, se fai imprescindible o estudo sobre a comunicación de cada unha das especialidades científicas, que no campo da comunicación xornalística estará forzosamente ligado ao estudo dos ámbitos de coñecemento nos que aquela se teña que contextualizar.

É neste campo onde este grupo de investigación pretende incidir. Un campo onde a comunidade científica que desenvolve proxectos relacionados coa teoría xeral da información e da comunicación ten avanzado pouco. Por outra parte, e xa focalizando o que dentro desa teoría se relaciona coa comunicación xornalística, este proxecto de investigación non fai das tecnoloxías ou da cues- 
tión técnica a súa estación términi. Pola contra, establecerá o seu ámbito de análise e reflexión sobre o fluxo de mensaxes compartidas que midan a súa intensidade estrutural e comunicativa pola súa maior ou menor porosidade ás distintas especialidades científicas. Algo que vai inevitablemente unido ás maneiras en que a elite que hoxe en día máis directamente conforma a realidade comunicativa -desde os propios medios de comunicación ata os ideólogos e os movementos de masas, desde os distintos especialistas na transmisión, almacenamento e uso da información ata os expertos nas técnicas de información- ten nese proceso unha maior ou menor capacidade interactiva.

En Galicia, esta investigación entra nun terreo practicamente virxe. Os estudos sobre medios centráronse ata o de agora case exclusivamente nas estruturas organizativas do sistema comunicativo galego e nas audiencias. Non incidiron apenas sobre a relación emisor-receptor. E moito menos sobre os procesos que deseñan, producen e codifican discursos xornalísticos que, valéndose de intermediarios profesionalizados e expertos, integren e xerarquicen coñecementos que as elites galegas estarían en condicións de ceder e compartir.

\section{AS PRINCIPAIS FONTES BIBLIOGRÁFICAS}

A bibliografía seleccionada -unha mostra dos textos básicos que serán útiles para o deseño e desenvolvemento da investigación- correspóndese co interese por:

1) Situar baixo que factores contraditorios se explica a necesidade de abordar periodisticamente o mundo contemporáneo con outras estruturas tanto organizativas como produtivas -velaí a obra dos teóricos da globalización e da sociedade da información e do coñecemento: Bell, Brzezinski, Castells, Lorn Norman, Martin, H. e Schumann, H., Matelartt, Nora S. e Minc, A., Postman e Cillinicos, entre outros-.

2) As relacións entre a cultura e a comunicación de masas, para contrastar valores normativos e valores funcionais nos medios de comunicación -velaí a obra de autores 
como Nielsen, Mattelart, Martín Barbero, Wolf ou Moragas-.

3) A complementación entre a democracia cognitiva e a democracia participativa leva a desafiar o poder dos medios a través da cantidade de coñecementos que son capaces de transmitir -velaí a obra de autores como Wilhelm, Varis, Smith, Skovman, M. e Christian, R., Nennett, L. e Entman, R, ou Curran-.

4) Os novos modelos comunicativos que facilitan a relación entre medios e sociedade, de forma que se constitúen aqueles en instrumentos válidos para a comunicación científica, especializada -autores como Bagdikian, Franklin, McManus, Lelucci, Potter, Thompson, Wolton, Timoteo Álvarez ou Fernández del Moral, entre outros-.

5) A escasa bibliografía producida ata agora sobre o sistema mediático galego -Álvarez Pousa, Campos, López, Túñez, Ledo Andión, Pousa Estévez, entre outros-. 